\title{
Dioscorea spp. Exploration at Manokwari Regency, West Papua, Indonesia
}

\author{
Paulus Chadikun $^{\# *}$, Amalia Tetrani Sakya ${ }^{\#}$, Vita Ratri Cahyani" ${ }^{\#}$ Maria Theresia Sri Budiastuti ${ }^{\#}$ \\ \# Doctoral Program of Agriculture Science, Graduate School, Sebelas Maret University, Surakarta, 57126, Indonesia \\ E-mail: pchadikun1962@student.uns.ac.id,sakya_at@yahoo.com,vitaratri@staff.uns.ac.id,budiastutiw@gmail.com \\ * Agriculture Faculty, Papua University, Manokwari, 98314, Indonesia \\ E-mail: chadikunpaulus@gmail.com (corresponding author)
}

\begin{abstract}
Yam (Dioscorea spp) is a useful plant. It is included among the top five tubers food crops contributing $99 \%$ of world production. These plants grow in a secondary forests in Manokwari Regency, West Papua, but it has not been cultivated yet by farmers or local communities, so it needs to be explored to identify its growing environment, morphological characteristics and its species variety. The Exploration was conducted in 9 districts of Manokwari Regency, West Papua which consisted of West Manokwari, South Manokwari, East Manokwari, North Manokwari, Masni, Prafi, Sidey, Tanah Rubuh, and Warmare, with a total area of $4650.32 \mathrm{~km}^{2}$. The exploration was carried out by determining randomly sampling points based on where the plants were found. Samples found were taken its photo, and collected its morphological character data and collected its dry specimens. The results found that the plant lives at a range temperature of $25.5-34.8^{0} \mathrm{C}, 57.7-88.2 \%$ humidity range, and light intensity range at $1033-$ 26200 lux. Forty accessions were obtained during the exploration comprising of 5 species i.e Dioscorea alata L., Dioscorea bulbifera L., Dioscorea hispida Dennst, Dioscorea pentaphylla L., and Dioscorea pyrifolia Kunth. The results showed that 2 accessions of Dioscorea alata $L$ had thorny stems and leave position of 2 other accessions were alternate; 2 accessions of Dioscorea bulbifera L. had thorny stems; and Dioscorea pentaphylla $L$ found to have compound leaves with 3, 4, 5 and 7 leaf blade.
\end{abstract}

Keywords — dioscorea; exploration; Manokwari; growing environment; morphological characteristics; species variety.

\section{INTRODUCTION}

Yam (Dioscorea spp) is a plant that is commonly found to grow in secondary forests and has not been cultivated yet by farmers or local communities in Manokwari regency. Therefore, the information about its morphological characteristic, growing environment, and its species variety are very limited. The exploration of this plant at Manokwari regency is needed to find out those information above.

Yam is a seasonal herbaceous vine plant from the Dioscoreaceae family. This family consists of around 650 species, 10 of which can be consumed, distribute in the tropical and subtropical regions, which are dioecious, twisting, vine, with large tuber in a single or group into a cluster [1], [2].

Dioscorea is a genus of monocotyledonous C3 plants that grow in the tropical regions as a food, pharmaceutical products and ornamental plants [3], [4], and are staple foods in West Africa, Southeast Asia and the Caribbean [5]. In Africa, yam is used as the main staple food and source of income for subsistence farmers. Yam is also the third most important tuber plant after cassava and sweet potatoes in West Africa, Central America, the Caribbean, the Pacific Islands and Southeast Asia [6].

Yam is included among the top five tubers food crops contributing $99 \%$ of world production, in the following order: potatoes $(46 \%)$, cassava $(28 \%)$, sweet potato $(18 \%)$, yam (6\%) followed by taro (1\%) [7]. This plant is potential to be used as a source of calories because it contains $73.1 \%$ starch and $1.85 \%$ sugar content [8]. In addition to its function as a provider of carbohydrates, yam is also used as a supplementary diet or herbal supplement and is believed may improve the function of the spleen, stomach and lungs [9]. This is related to the presence of various chemical compounds in this plant [10], such as Dioscorin and Diosgenin which are immunoactive [11], [12], [13]. Dioscorin contained in some species of plants has the ability as antioxidants, antihypertension, immune system modulation, lectin activity, etc [14]. While Diosgenin, which useful as a food and non-food source is beneficial to health with the ability to reduce cholesterol and anti-cancer [15], [16]. Different species and cultivars of Yam grown in different places may have different composition and 
nutritional value [17]. The advantage this plant is that it contains antinutrients and secondary metabolites, in addition to its nutrients that play a role as food ingredients [18]. Yam is also included in a tropical plant that is tolerant to shade but considering as a subsistence plant, not a cultivated staple plant, because its utilization is still limited to household consumption [19].

The species including in the Dioscorea genus may originate from Southeast Asia [20]. The diversity of Dioscorea species in the three separated continents: West Africa, Southeast Asia and Tropical America [21] is because of the evolution differentiation as a result of the formation of the Atlantic Ocean and the drying of the Middle East [22].

The purpose of this exploration is to observe the environmental conditions in which the dioscorea plant grows, characterize its morphology, and identify its species variety in Manokwari regency, West Papua.

\section{MATERIAL AND METHOD}

This is an explorative descriptive research with survey methods. The survey was conducted in all districts in Manokwari Regency, which consisted of: West Manokwari, South Manokwari, East Manokwari, North Manokwari, Masni, Prafi, Sidey, Tanah Rubuh, and Warmare, with a total area of $4650.32 \mathrm{~km}^{2}$ (Figure 1). Manokwari Regency is one of 13 regencies in West Papua Province, which is geographically located at $0^{0} 15^{\prime} \mathrm{SL}-3^{0} 25^{\prime} \mathrm{SL}$ and $132^{0} 35^{\prime} \mathrm{EL}-$ $134^{\circ} 45^{\prime} \mathrm{EL}$, with a temperature of $24.9^{\circ} \mathrm{C}-31.4^{\circ} \mathrm{C}$ and air humidity $66.3 \%-94.3 \%$ [23]. The exploration was conducted from September 2018 to February 2019.

Exploration techniques was carried out by determining randomly sampling points based on where the plants were found. Samples found were taken its photo, and collected its morphological character data and collected to get its dry specimens. Morphological character data collected were growth type as well as character of stems, leaves, petiole, flowers and fruit.

Each accession found in the field is recorded its growing condition temperature and humidity by using Humidity and Temperature Meter AS837 type, and light intensity using a Digital Lux Meter type AR813A Smart Sensor Intell Instruments Plus.

Dry specimens were prepared from leaves, stems, flowers and fruit by using Precision Economyc Gravity Convection Oven brand SHEL LAB. for 7 days at 550C. The dried specimens were then sent to be species identified in "Herbarium Bogoriense", Botany Field Research Center for Biology, Indonesian Institute of Sciences, Bogor, Indonesia.
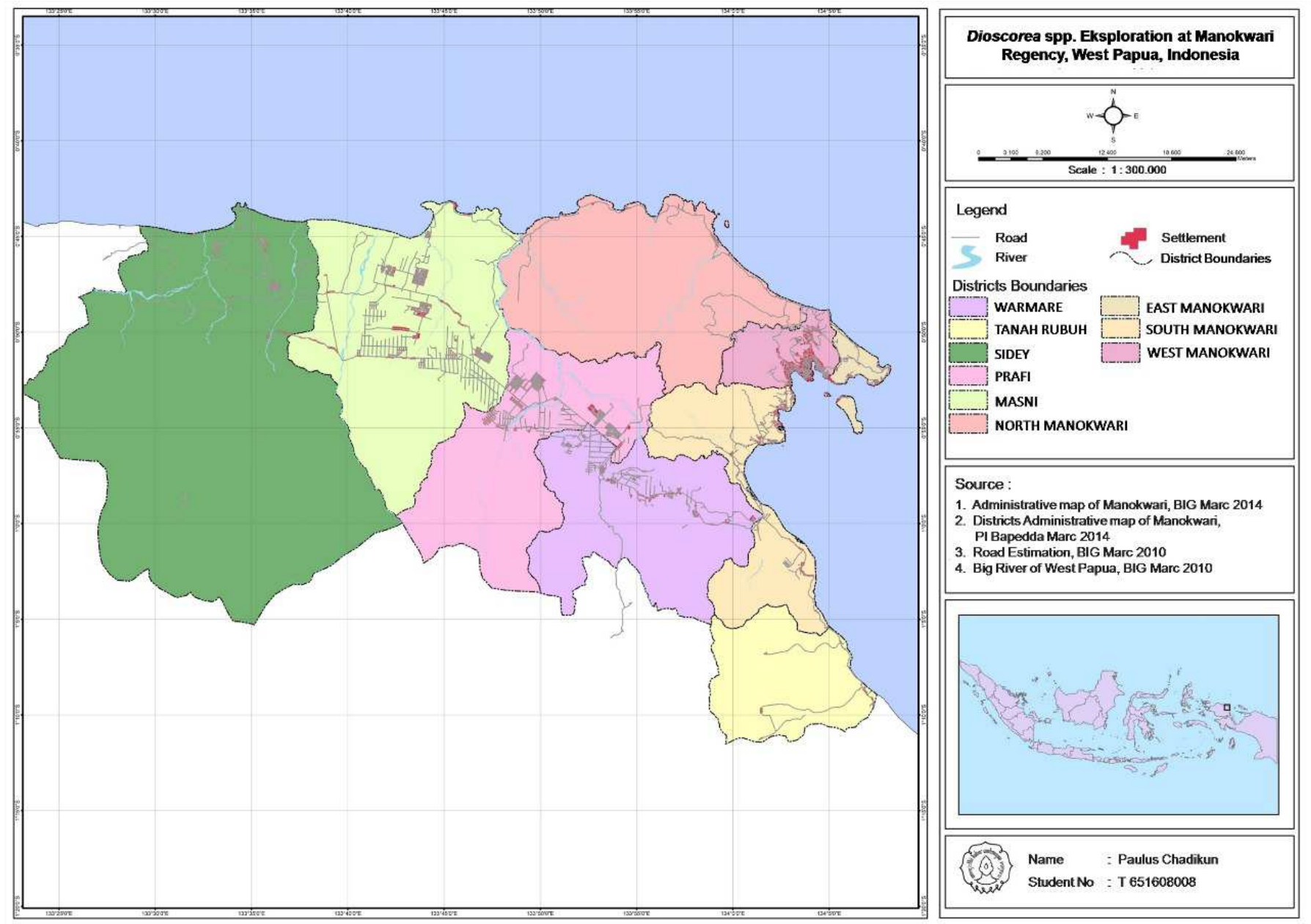

Fig 1. Manokwari Regency Map 


\section{RESULT AND DISCUSSION}

\section{A. Result}

The exploration results in 9 Districts at Manokwari Regency found 43 suspected accessions of Dioscorea spp, however, identification results based on morphological character obtained only 40 accessions as Dioscorea genus consisting of 5 species, Dioscorea alata L., Dioscorea bulbifera L., Dioscorea hispida Dennst, Dioscorea pentaphylla L., and Dioscorea pyrifolia Kunth (Table 1).

The exploration found 11 Dioscorea alata L. plants in 6 districts with 3 plants having tubers; 13 Dioscorea bulbifera
L. plants in 7 districts with 8 plants having tubers, 2 plants having aerial tubers and 1 plant having flowers; Dioscorea hispida Dennst which had tubers were the Dioscorea that only found at Prafi District and not at other regions; 10 Dioscorea pentaphylla L. plants found in 8 districts with 7 plants having tubers, 2 plants having aerial tubers, 3 plants having no bulbs or aerial tubers, 2 plants having flowers and 1 plant having fruit; 5 Dioscorea pyrifolia Kunth plants found in 4 districts and all of them did not have tubers.

TABLE I

DIOSCOREA SPP. IDENTIFICATION IN DISTRICTS AT MANOKWARI REGENCY

\begin{tabular}{|c|c|c|c|c|c|}
\hline No. & Districts & Aksesi Code & Scientific Name & Tuber & Aerial Tuber \\
\hline \multirow[t]{2}{*}{ I. } & North Manokwari & $\begin{array}{l}\text { PC-02 } \\
\text { PC-03 } \\
\text { PC-04 } \\
\text { PC-05 } \\
\text { PC-06 } \\
\text { PC-43 } \\
\text { PC-44 }\end{array}$ & $\begin{array}{l}\text { Dioscorea pyrifolia Kunth } \\
\text { Dioscorea alata } \mathrm{L} . \\
\text { Dioscorea bulbifera } \mathrm{L} . \\
\text { Dioscorea pentaphylla } \mathrm{L} \text {. } \\
\text { Dioscorea alata } \mathrm{L} . \\
\text { Dioscorea bulbifera } \mathrm{L} . \\
\text { Dioscorea bulbifera } \mathrm{L} .\end{array}$ & $\begin{array}{l}\text { V } \\
\text { V } \\
\text { V } \\
\text { V }\end{array}$ & $\mathrm{V}$ \\
\hline & Total & & 7 & 4 & 1 \\
\hline \multirow[t]{2}{*}{ II. } & East Manokwari & $\begin{array}{l}\text { PC-07 } \\
\text { PC-09 }\end{array}$ & $\begin{array}{l}\text { Dioscorea alata } \mathrm{L} . \\
\text { Dioscorea pentaphylla } \mathrm{L} .\end{array}$ & & \\
\hline & Total & & 2 & - & - \\
\hline \multirow[t]{2}{*}{ III. } & South Manokwari & $\begin{array}{l}\text { PC-10 } \\
\text { PC-11 } \\
\text { PC-12 } \\
\text { PC-13 } \\
\text { PC-14 } \\
\text { PC-15 } \\
\text { PC-16 }\end{array}$ & $\begin{array}{l}\text { Dioscorea bulbifera } \mathrm{L} . \\
\text { Dioscorea pyrifolia Kunth } \\
\text { Dioscorea pyrifolia Kunth } \\
\text { Dioscorea alata } \mathrm{L} \text {. } \\
\text { Dioscorea pentaphylla } \mathrm{L} \text {. } \\
\text { Dioscorea alata } \mathrm{L} \text {. } \\
\text { Dioscorea alata } \mathrm{L} .\end{array}$ & $\begin{array}{l}\mathrm{V} \\
\mathrm{V} \\
\mathrm{V}\end{array}$ & V \\
\hline & Total & & 7 & 4 & 1 \\
\hline \multirow[t]{2}{*}{ IV. } & West Manokwari & $\begin{array}{l}\text { PC-17 } \\
\text { PC-18 } \\
\text { PC-19 } \\
\text { PC-21 } \\
\text { PC-22 } \\
\text { PC-24 } \\
\text { PC-25 }\end{array}$ & $\begin{array}{l}\text { Dioscorea pentaphylla } \mathrm{L} \text {. } \\
\text { Dioscorea bulbifera } \mathrm{L} . \\
\text { Dioscorea bulbifera } \mathrm{L} . \\
\text { Dioscorea pyrifolia Kunth } \\
\text { Dioscorea alata } \mathrm{L} . \\
\text { Dioscorea alata } \mathrm{L} . \\
\text { Dioscorea alata } \mathrm{L} . \\
\end{array}$ & $\mathrm{V}$ & \\
\hline & Total & & 7 & 1 & - \\
\hline \multirow[t]{2}{*}{ V. } & Warmare & $\begin{array}{l}\text { PC-26 } \\
\text { PC-27 } \\
\text { PC-28 } \\
\text { PC-29 } \\
\text { PC-30 } \\
\text { PC-31 }\end{array}$ & $\begin{array}{l}\text { Dioscorea bulbifera } \mathrm{L} . \\
\text { Dioscorea pentaphylla } \mathrm{L} \text {. } \\
\text { Dioscorea pyrifolia } \mathrm{Kunth} \\
\text { Dioscorea bulbifera } \mathrm{L} . \\
\text { Dioscorea bulbifera } \mathrm{L} . \\
\text { Dioscorea pentaphylla } \mathrm{L} \text {. }\end{array}$ & $\begin{array}{l}\mathrm{V} \\
\mathrm{V}\end{array}$ & \\
\hline & Total & & 6 & 4 & - \\
\hline \multirow[t]{2}{*}{ VI. } & Sidey & $\begin{array}{l}\text { PC-32 } \\
\text { PC-33 } \\
\text { PC-34 } \\
\text { PC-35 }\end{array}$ & $\begin{array}{l}\text { Dioscorea bulbifera } \mathrm{L} . \\
\text { Dioscorea pentaphylla } \mathrm{L} . \\
\text { Dioscorea alata } \mathrm{L} . \\
\text { Dioscorea pentaphylla } \mathrm{L} .\end{array}$ & V & $\begin{array}{l}\mathrm{V} \\
\mathrm{V}\end{array}$ \\
\hline & Total & & 4 & 1 & 2 \\
\hline \multirow[t]{2}{*}{ VII. } & Masni & $\begin{array}{l}\text { PC-36 } \\
\text { PC-37 }\end{array}$ & $\begin{array}{l}\text { Dioscorea bulbifera } \mathrm{L} . \\
\text { Dioscorea pentaphylla } \mathrm{L} \text {. }\end{array}$ & $\begin{array}{l}\mathrm{V} \\
\mathrm{V}\end{array}$ & \\
\hline & Total & & 2 & 2 & - \\
\hline \multirow{2}{*}{ VIII. } & Prafi & PC-38 & Dioscorea hispida Dennst & $\mathrm{V}$ & \\
\hline & Total & & 1 & 1 & - \\
\hline \multirow[t]{2}{*}{ IX. } & Tanah Rubuh & $\begin{array}{l}\text { PC-39 } \\
\text { PC-40 } \\
\text { PC-41 } \\
\text { PC-42 }\end{array}$ & $\begin{array}{l}\text { Dioscorea bulbifera } \mathrm{L} . \\
\text { Dioscorea bulbifera } \mathrm{L} . \\
\text { Dioscorea alata } \mathrm{L} . \\
\text { Dioscorea pentaphylla } \mathrm{L} .\end{array}$ & $\begin{array}{l}\text { V } \\
\text { V }\end{array}$ & \\
\hline & Total & & 4 & 2 & - \\
\hline & Total & & 40 & 19 & 4 \\
\hline
\end{tabular}




\section{1) Discorea alata L.}

Stem : climbing, twining to the right/clockwise (Figure 2a), height 4 - $6 \mathrm{~m}$, part of the base of the stem is light green and some is dark green, the wings at the base stem are light purple (Figure 2b), the stem apex is dark green to light green, the stem base diameter $0.1-1.5 \mathrm{~cm}$, stem apex diameter is $0.1-0.4 \mathrm{~cm}$, the shape of the base of the stem is round to quadrangular, the base of the stem is smooth to wrinkle, some stem have spine (Figure 2c) and some do not, spines are sparse to solid on the stem, the length of the thorns $<2$ $\mathrm{mm}$, the shape of the thorn is straight to curved upwards, the color thorns is green to light purple, some stems are winged and some are wingless, the color of the wings is light green to light purple, some of the surface of the stem is slippery and partly have dense soft hair.

Leaf : Single leaf, opposite (Figure 2d) to alternate and alternate at one side persistent (Figure 2e), leaf width 1/3 leaf length, 1 leaf to a pair of leaves each segment, leave margin entire, deeply lobed, leaf thin and flabby to thick and stiff, leaf colour are dark green (upper surface) and light green (lower surface), longitudinal venation, leaf vein colour are dark green (upper surface) and light green (lower surface), leaf margin colour are dark green (upper surface) and light green (lower surface), the hairiness of upper/lower surface of leaf is smooth to sparse, waxy upper surface of the leaf, leaf shape cordate, leaf apex acute, leaf base cordate, intermediate lobed leaf, leaf and leaf lobes roll/folding upward, lobe length to leaf tip x leaf width $(5-10.5 \mathrm{~cm}) \mathrm{x}$ $(2.8-7 \mathrm{~cm})-(20-26 \mathrm{~cm}) \times(13-15 \mathrm{~cm}))$, the length of the lobe to the base of the leaf $(0.8-2 \mathrm{~cm})-(2.5-3.5 \mathrm{~cm})$, the length of leaf tip $0.3-2 \mathrm{~cm}$, width of lobe $2.8-18 \mathrm{~cm}$, the widest part of leaf at $1 / 3$ base of leaf to center of leaf.

Petiole : petiole shape cylinders to quadrangular, length $3.5-9 \mathrm{~cm}$, dense soft hair, petiole color green or some with base or tip petiole purple.

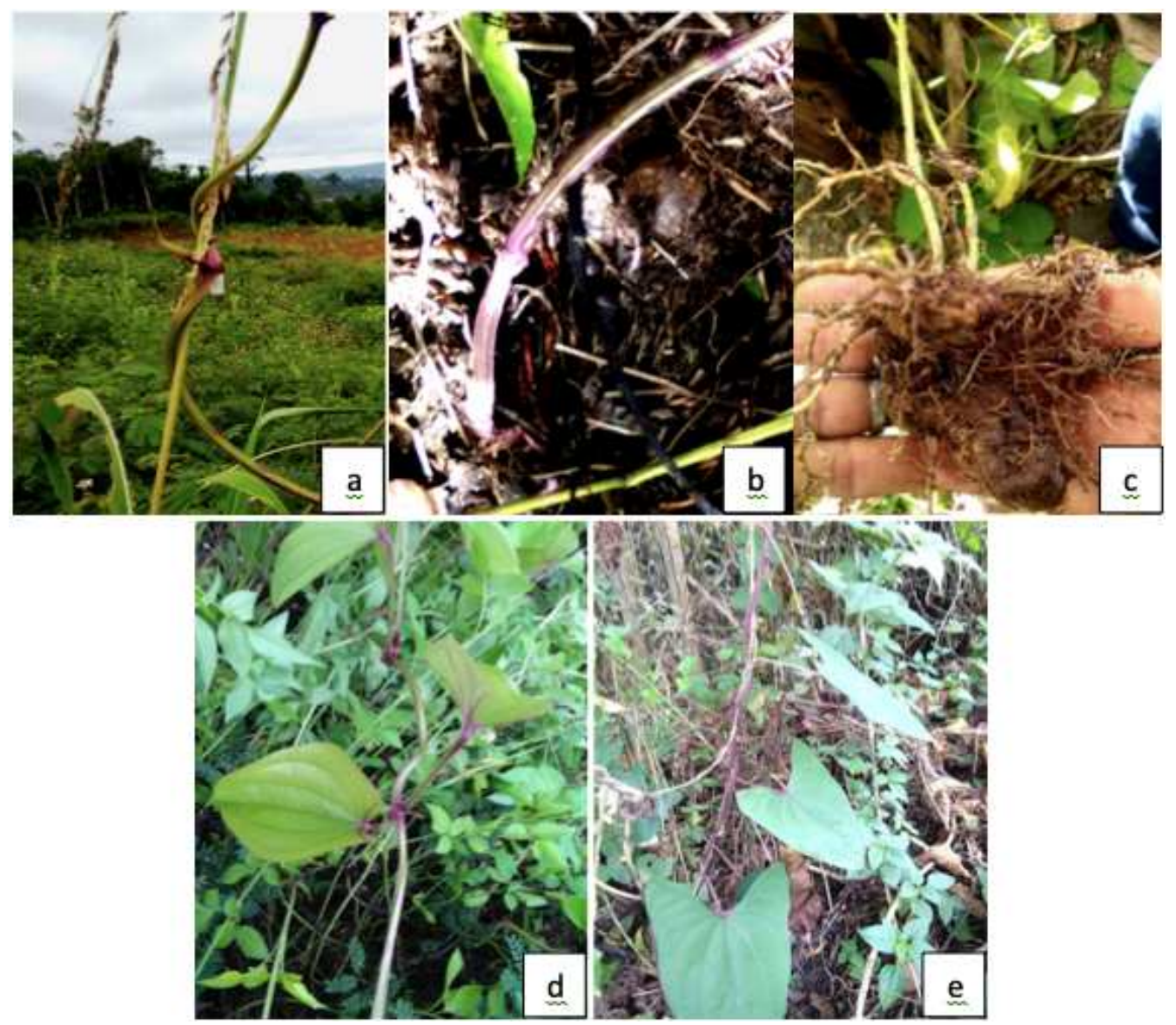

Fig 2. Some of Dioscorea alata Found in Manokwari Regency (a). twinning to the right; (b). winged stem base; (c). spine stem; (d). opposite leaf; (e). alternate leaf.

\section{2) Dioscorea bulbifera L.}

Stem: Climbing, twinning to the left/counterclockwise (Figure 3a), height $6 \mathrm{~m}$ to $8 \mathrm{~m}$, whole stems dark green to light green, some have spine and some do not, stem base diameter $0.4 \mathrm{~cm}$, the shape of the base of the stem is round to quadrangular (Figure $3 \mathrm{~b}$ ), the stem diameter towards the tip is $0.3 \mathrm{~cm}$, there is wing at the base of the stem (Figure
$3 b)$, the base of the stem is partially have dense spine and some have not.

Leaf : single leaf, alternate (Figure 3a), 1 leaf per segment, width $2 / 3$ leaf length/close to round (Figure 3c), leaf margin entire, deeply lobed, flabby leaf, leaf colour dark green (upper surface) and light green (lower surface), longitudinal venation, leaf vein colour are dark green (upper surface) and light green (lower surface), leaf margin colour are dark green (upper surface) and light green (lower surface), the hairiness 
of upper/lower surface of leaf is sparse, leaf shaped cordate, leaf apex acute, leaf base cordate, intermediate lobed leaf, leaf and leaf lobes roll/folding upward, lobe length to leaf tip $\mathrm{x}$ leaf width $(5.5-13 \mathrm{~cm}) \times(5-9.5 \mathrm{~cm})-(14-24 \mathrm{~cm}) \times(11-18$ $\mathrm{cm})$, the length of the lobe to the base of the leaf $(1.8-4 \mathrm{~cm})$ $(3-7 \mathrm{~cm})$, the length of leaf tip $0.5-2 \mathrm{~cm}$, width of the lobe $(3-6 \mathrm{~cm})-(10-12 \mathrm{~cm})$, the widest part of the leaf is the base of the leaf.
Petiole : length of petiole $5.5-9 \mathrm{~cm}$, dense soft hair, round shape, petiole color is brownish green with the base and the tips are green to light brown.

Flower : inflorescens type, inflorescence position under axillary (Figure 3d), number of inflorescences $<10$ per plant, inflorescence type raceme (Figure 3e), inflorescence length $>16 \mathrm{~cm}$, flower color light green.

Aerial tuber : located in the axillary, $2.5 \mathrm{~cm}$ in diameter, dark brown and light brown (Figure 3f).

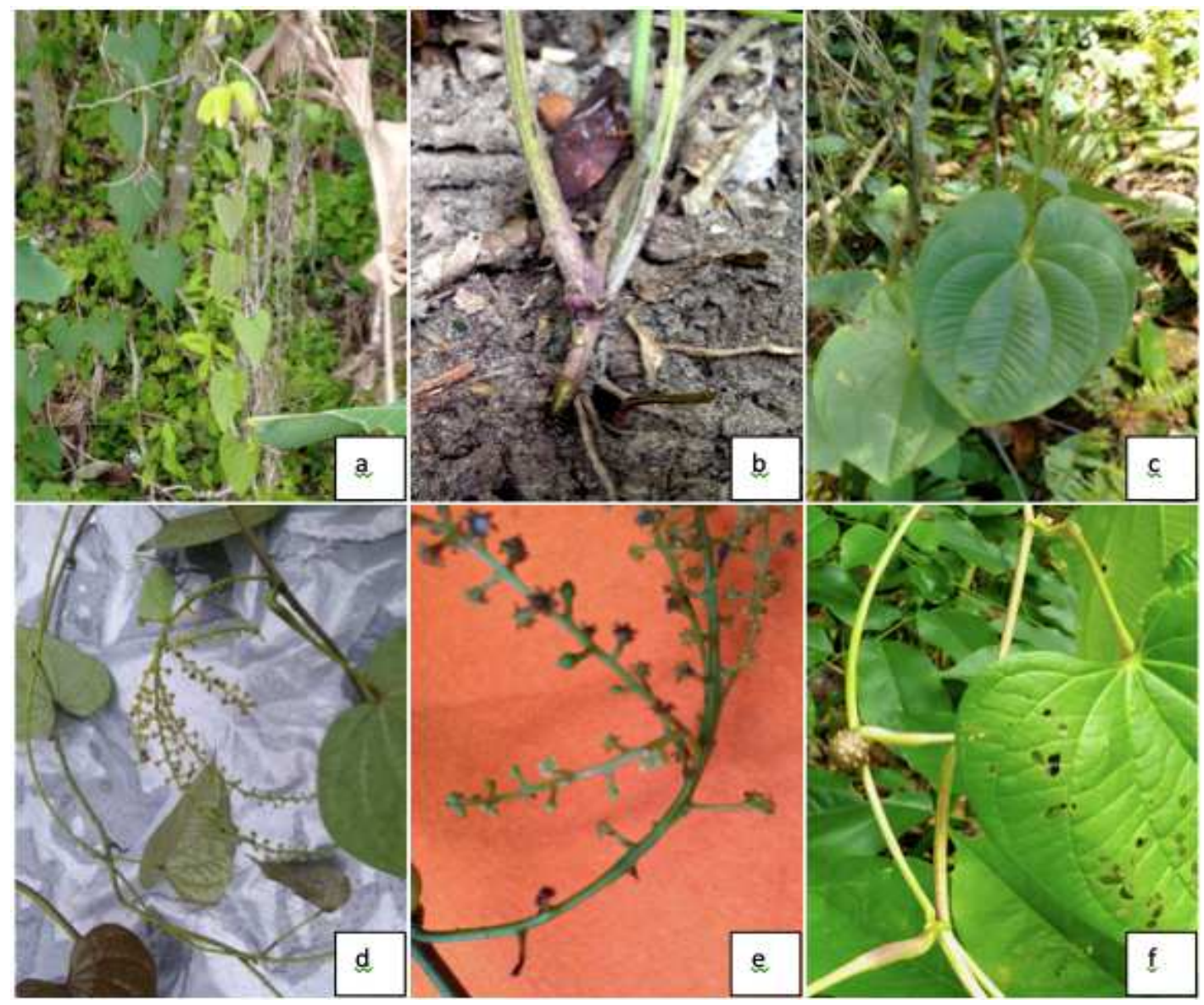

Fig 3. Some of Dioscorea bulbifera Found in Manokwari Regency (a). twinning to the left and alternate leaf; (b). Quandrangular and winged stem base; (c). Leaf width 2/3 of leaf length; (d). Flower position axillary; (e). Inflorescence type raceme; (f). aerial tuber.

\section{3) Dioscorea hispida Dennst.}

Stem : Climbing, twinning to the left (counterclockwise), height $9 \mathrm{~m}$, stem base light green and darker to the tip, stem base diameter $1.4 \mathrm{~cm}$, the shape of stem base is round, having no wing, having dense spine (Figure 4a).

Leaf : compound leaf (Figure 4b), verticillate, 3 leaf per segment, leaf margin entire, no lobed, flabby leaf, leaf colour dark green (upper and lower surface), longitudinal venation (Figure 4c), leaf vein colour are dark green (upper and lower surface), leaf margin colour are dark green (upper and lower surface), leaf shape elliptical to lanceolate, leaf apex acute, leaf base obtuse (Figure 4c), leaf roll/folding upward, leaf length $12-22 \mathrm{~cm}$, leaf apex length $1-2 \mathrm{~cm}$, leaf width $8.5-13.5 \mathrm{~cm}$, the widest part of leaf at $1 / 3$ base of leaf.

Petiole : length $6-13 \mathrm{~cm}$, dense soft hair, spine, round shape, all parts in light green colour.

\section{4) Dioscorea pentaphylla L.}

Stem : Climbing, Climbing, twinning to the left/counterclockwise (Figure 5a), height 3 - $5 \mathrm{~m}$, stem colour in dark green to light brown, stem base diameter $0.4-0.8 \mathrm{~cm}$ and $0.2-0.4 \mathrm{~cm}$ to the apex, the shape of stem base is round, having no hair and wing, having spine.

Leaf : compound leaf, palmate, having 3 (Figure 5b), 4, 5 (Figure 5c) up to 7 leaf per segment (Figure 5d), leaf margin entire, no lobed, flabby leaf, some have leaf colour dark green (upper surface) and light green (lower surface) and some have leaf colour dark green (upper and lower surface), pinnate venation, some have leaf vein colour dark green (upper surface) and light green (lower surface) and some have leaf vein colour dark green (upper and lower surface), some have leaf margin colour dark green (upper surface) and light green (lower surface) and some have leaf margin colour dark green (upper and lower surface), both surfaces have hairy texture, leaf shape lanceolate, leaf apex acute, leaf base 
obtuse, leaf length $4-16 \mathrm{~cm}$, leaf apex length $0.3 \mathrm{~cm}$, leaf width $2-6 \mathrm{~cm}$, the widest part of leaf at 1/3 leaf apex.

Petiole : length $4-11 \mathrm{~cm}$, dense soft hair, spine, round shape, have green colour with base and tip in light brown colour
Flower : inflorescens type spike (Figure 5e), inflorescence position under axillary, inflorescence length $>30-40 \mathrm{~cm}$.

Fruit : in capsule form (Figure 5f).

Aerial tuber : located in the axillary, $3.5 \mathrm{~cm}$ in diameter, dark brown and light brown (Figure 5c).

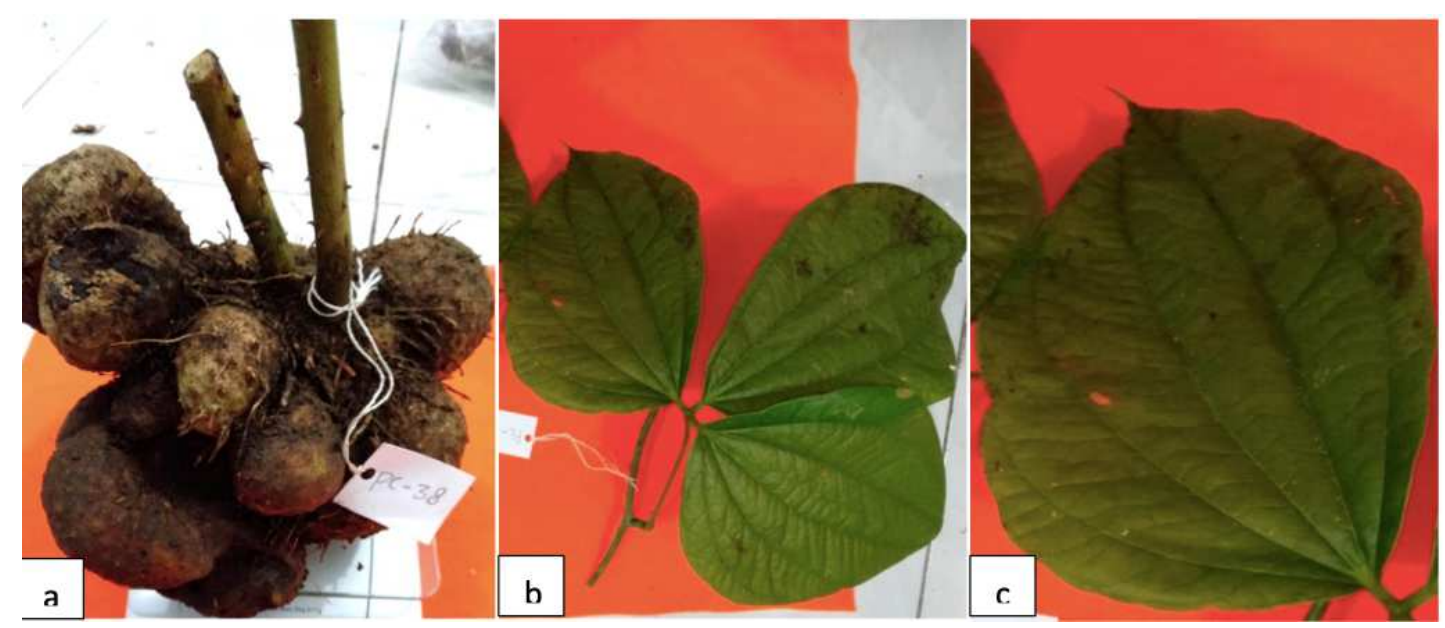

Fig 4. Some of Dioscorea hispida found in Manokwari Regency (a). Spine stem base, round shape, winged; (b). Compound leaf composition; (c). Longitudinal leaf vein in obtuse shape.

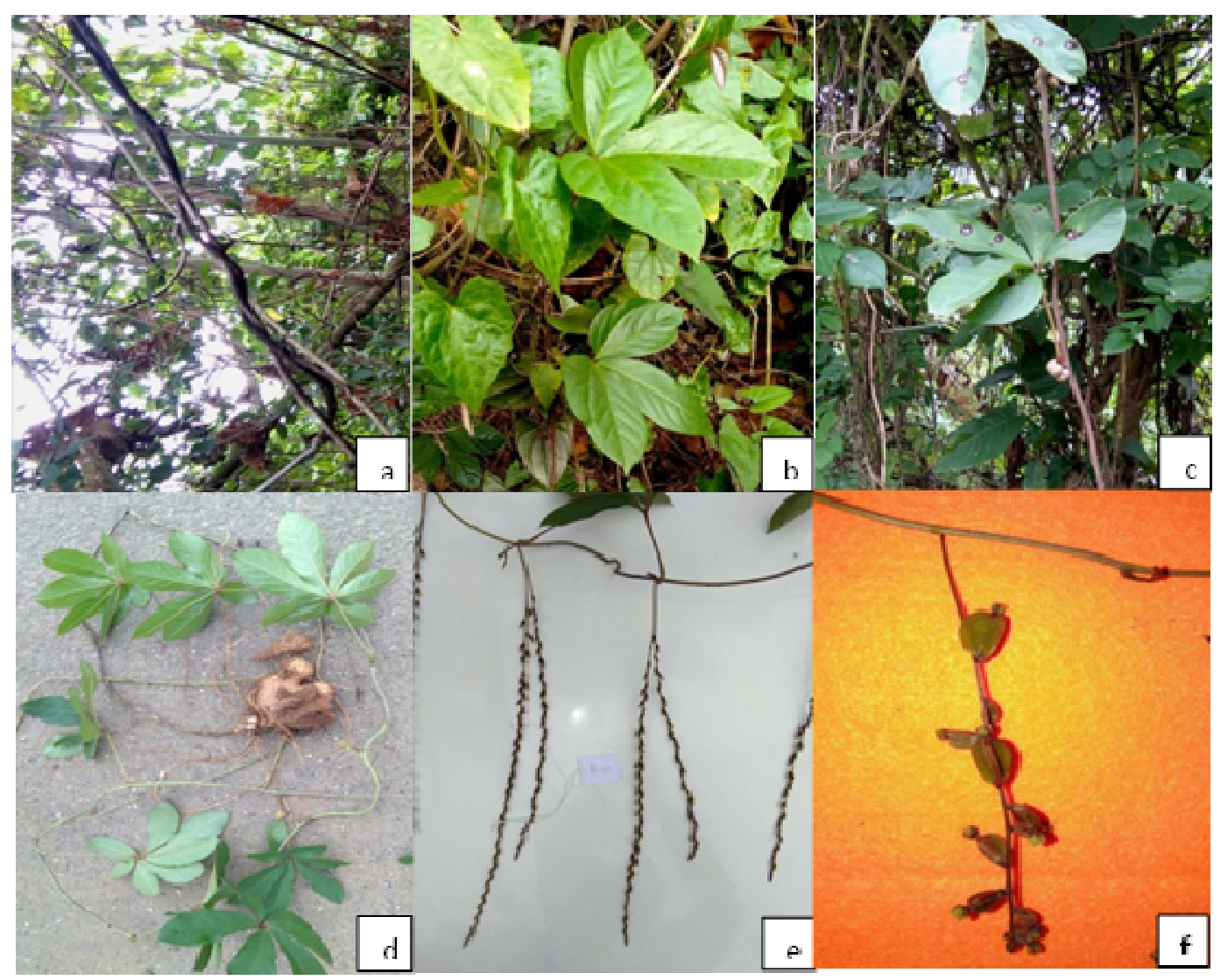

Fig 5. Some of Dioscorea pentaphylla found in Manokwari Regency (a). twinning to the left; (b). Compound leaf with 3 leaves; (c). Compound leaf with 5 leaves and aerial tuber; (d). Compound leaf with 7 leaves; (e) Inflorescence spike; (f). Capsule fruit;. 


\section{5) Dioscorea pyrifolia Kunth}

Stem : Climbing, twinning to the right/clockwise (Figure 6a), height $5-6 \mathrm{~m}$, stem base dark green and lighter to the tip, stem base diameter $0.2-0.6 \mathrm{~cm}$, the shape of stem base is round (Figure 6b), having no wing, having dense spine in the base (Figure 6b) and not above.

Leaf : single leaf, opposite (Figure 6d) and some alternate (Figure 6c), 1 leaf per segment, leaf margin entire, shallowed lobed (Figure 6c), flabby leaf, leaf colour dark green (upper surface) and light green (lower surface), longitudinal venation, leaf vein colour dark green (upper surface) and light green (lower surface), leaf margin colour dark green (upper surface) and light green (lower surface), both surfaces have hairy texture, leaf shape cordate, leaf apex acute, leaf base cordate, intermediate lobed leaf, leaf and leaf lobed slightly roll/folding upward, length of lobe to apex leaf 10 $13 \mathrm{~cm}$, length of lobe to base leaf $0.3-0.5 \mathrm{~cm}$, leaf apex length $1 \mathrm{~cm}$, leaf width $5.5-10 \mathrm{~cm}$, the widest part of leaf at the base.

Petiole : length of petiole $6 \mathrm{~cm}$, dense soft hair, round shape, petiole color is light green.

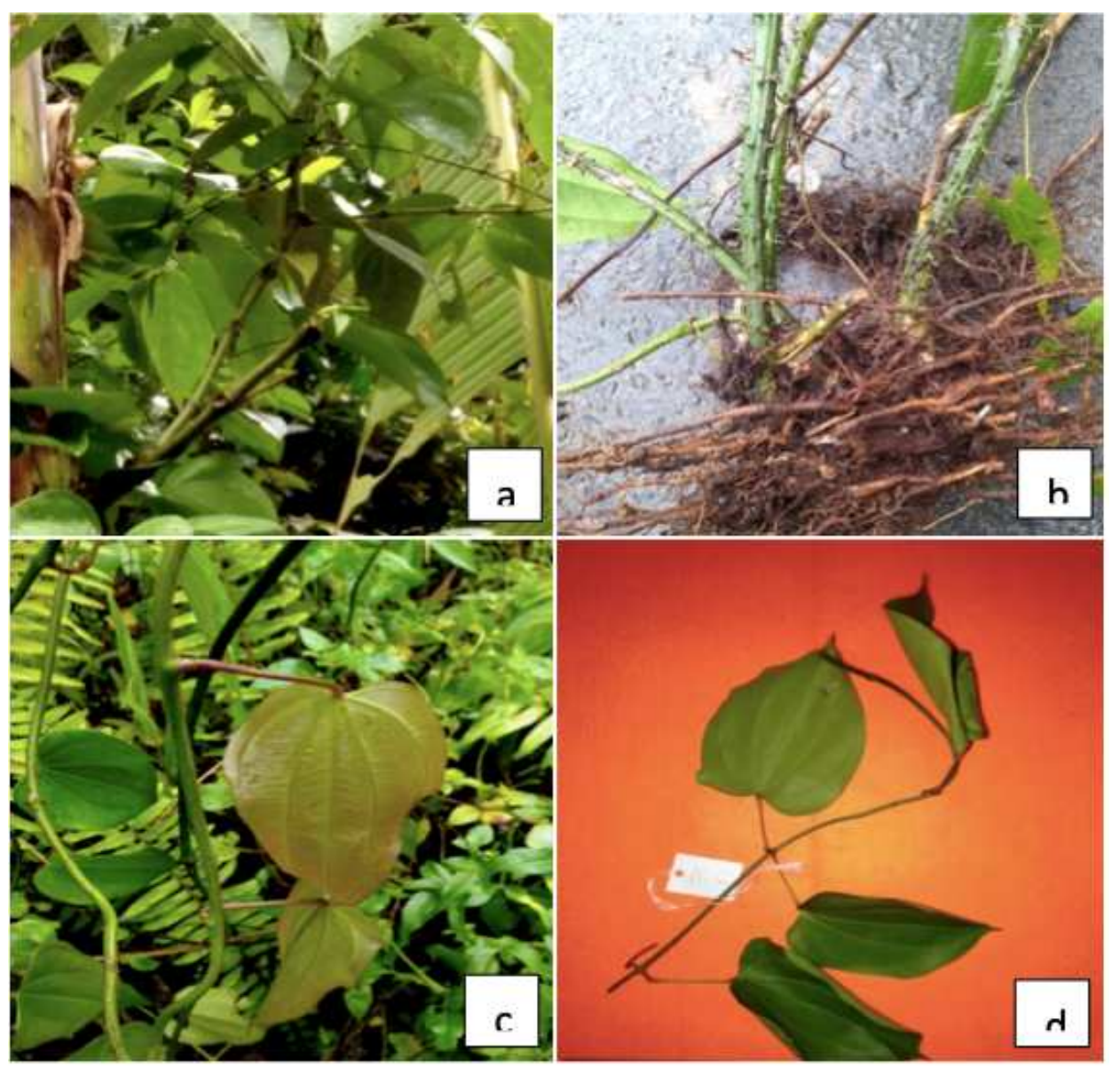

Fig 6. Some of Dioscorea pyrifolia found in Manokwari Regency (a). twinning to the right; (b). Spine stem base in round shape; (c). Single leaf in alternate with shallowed lobed; (d). Single leaf in opposite.

\section{B. Discussion}

The exploration found 5 species in Manokwari Regency, namely Dioscorea alata L., Dioscorea bulbifera L., Dioscorea hispida Dennst, Dioscorea pentaphylla L., and Dioscorea pyrifolia Kunth. Among these the five species there are 3 species have been cultivated in the world, namely D. alata L., D. bulbifera L., and D. pentaphylla L. [24].

Dioscorea alata L. (huwi / Sundanese; uwi / Javanese, Water Yam / Greater Yam) is currently a very diverse and widespread species [18] and is economically important and originating from Southeast Asia, Myanmar and Thailand [25], [26]. This species was found in the temperature range of $27.1-34.8{ }^{\circ} \mathrm{C}$, humidity $57.7-83.7 \%$ and light intensity 1156 - 24700 lux. There were only 2 plants (PC-24 and PC-
25) from West Manokwari district having spine stem from the total of $11 \mathrm{D}$. alata plants were found in Manokwari Regency. The position of the leaves were not only found to be opposite, but also alternate (PC-15 and PC-03) but only on one side (Figure 2e) because of the stem rotation was affected by the twinning character (PC 15).

Dioscorea bulbifera L. (Gembolo / Aerial Yam) is the most popular species after D. alata which originates from Asia in general, tropical Africa and Northern Australia [20], [27], [28]. This species is spread to central and southern America, Africa, Australia, Louisiana, Texas, Hawaii, Puerto Rico, Polynesia, Florida, and West Africa [20], [29], [30]. At Manokwari, it was found at a range of temperature at 26.3 $32.7{ }^{0} \mathrm{C}$, humidity $57.8-86.4 \%$ and light intensity 1238 26200 lux. The stem of Dioscorea bulbifera L. (PC-29 and 
PC-43) was also found to have spine. It has light green inflorescence colour (PC-30) and aerial tuber colour in black brown (PC-32) and light brown (PC-44).

Dioscorea pentaphylla L. (Tomboreso/Five Leaf Yam) is the species with the largest tuber originating from tropical Asia and Eastern Polynesia, which then spread to Southeast Asia, Kauai, Molokai, Hawaii, Tahiti, Savii, North America and Florida [31]. In Manokwari, it was found in the range of temperature at $26.6-32.5{ }^{\circ} \mathrm{C}$, humidity $60.3-85.7 \%$ and light intensity 2840 - 26200 lux. This species has compound leaves with 3 leaves (PC-31); 4 leaves (PC-35, PC-33): 5 leaves (PC-37, PC-17, PC-42, PC-05, PC-35, PC-33, PC-27, $\mathrm{PC}-09)$ and 7 leaves ( $\mathrm{PC}-14$ ). This species was found to have flowers on PC-33, PC-37 and fruit on PC-37. Its aerial tuber colour were dark brown (PC-14) and light brown (PC33).

Dioscorea hispida Dennst (Gadung / Bitter Yam) originates from southern Asia [20] and spreads in tropical and subtropical regions of the Philippines, China, Taiwan, Malaysia, New Guinea, Fujian, Bhutan, Indonesia, Bangladesh, Sikkim, Thailand, Cambodia , Laos, Myanmar, Vietnam and Africa [32], [33]. It was found in Manokwari at temperature of $25.5^{\circ} \mathrm{C}$, humidity of $88.2 \%$ and night time so that the light intensity cannot be measured.

Dioscorea pyrifolia Kunth (uwi upas / Sundanese; ilus / Javanese), with synonyms $D$. diepenhorstii Miquel, $D$. oppositifolia L. sensu auct. Mult., D. zollingeriana Kunth., was found in Manokwari at a range of temperature at 27.1 $32.7{ }^{0} \mathrm{C}$, humidity $62.4-84.7 \%$ and light intensity 1033 18160 lux.

Yam were found to always growing by climbing upwards to other plants because of the presence of twining characters (right or left) and the wings on the stem. The found of 19 plants of 4 species from the total of 40 accessions which produced tuber were related to the age of the plants that was mature enough to produce tuber which is 5 month at lowland and $9-10$ month at highland [34]. Furthermore, the environmental conditions that are suitable in terms of temperature, humidity and light intensity also support the formation of tubers. Aerial tuber were found at 2 plants each of Dioscorea pentaphylla dan Dioscorea bulbifera might related to the character and length of the day (shorter length day) which affected the formation of aerial tuber [18]. Flower was found at Dioscorea bulbifera species, while Dioscorea pentaphylla was found to produce flower and fruit because of its age reach generative phase and supported by appropriate micro climate.

\section{CONCLUSIONS}

Dioscorea plants are found in Manokwari in the temperature range of $25.5-34.8{ }^{\circ} \mathrm{C}$, the humidity range is $57.7-88.2 \%$ with a light intensity range of 1033 lux-26200 lux. Two accessions of Dioscorea alata L had spined stems and leave position of 2 other accessions were alternate; 2 accessions of Dioscorea bulbifera L. had thorny stems; and Dioscorea pentaphylla L. found to have compound leaves with 3, 4, 5 and 7 leaf blade. Forty accessions were obtained during the exploration comprising of 5 species i.e Dioscorea alata L., Dioscorea bulbifera L., Dioscorea hispida Dennst, Dioscorea pentaphylla L., dan Dioscorea pyrifolia Kunth.

\section{ACKNOWLEDGMENT}

The authors would like to thank Alex Wihyawari, Yuno Heipon, Ronald Edoway, Clements Ergor, Papua J. Mayor, Kristian Awairaro, Viktor Simbiak, Alfredo O. Wanma and Wolfram Y. Mofu for their support and assistance in the field exploration and preparation of dry specimens.

\section{REFERENCES}

[1] Acevedo-Rodriguez, P., 2005. Family Dioscoreaceae. In: Vines and Climbing Plants of Puerto Rico and the Virgin Islands. Smithsonian Institution. Contributions from the United States National Herbarium, Vol.51: 421-427.

[2] Acevedo-Rodrguez, P., and Strong, M.T,, 2005. Family 10. Dioscoreaceae Yam Family. In: Monocotyledons and Gymnosperms of Puerto Rico and the Virgin Islands. Contributions from the United States National Herbarium, Vol.52: 82-92.

[3] Ayensu, E.S., 1972. Anatomy of Monocotyledon. VI: Dioscoreales. Oxford University Press,London. UK.

[4] Cornet, T., Sierra, J., and Bonhomme, R., 2007. Characterization of the Photosynthetic pathway of some tropical food yams (Dioscorea spp.) using leaf natural ${ }^{13} \mathrm{C}$ abundance. Photosynthetica 45 (2): 303305 .

[5] Akoruda, M.O., 1984. Genetic improvement of vegetable crops: yam (Dioscorea spp.). In M. Kasloo (ed.), Genetic improvement of vegetable crops. Pergamon Press, pp. 717-733.

[6] Srivastava, A.K., and Gaiser, T., 2008. Biomass production and partitioning pattern of Yam (Dioscorea rotundata). Agric. J. 3: 334337.

[7] Jayakody, L., Hoover, R., Liu, Q., Donner, E., 2007. Studies on tuber starches. II. Molecular structure, composition and physicochemical properties of yam (Dioscorea sp.) starches grown in Sri Lanka. Carbohydrate Polymers, 69(1), pp.148-163. Elsevier.

[8] Lebot, V., R. Malapa, T. Molisale, J. L. Marchand. 2005. Physicochemical characterization of yam (Dioscorea alata L.) tubers from Vanuatu. Genet. Resour. Crop Evol. 53:1199-1208.

[9] Huang CH, Cheng JY, Deng MC, Chou CH Jan TR. 2012. Prebiotic effect of diosgenin, an immunoactive steroidal sapogenin of chinese yam. Food Chemistry. 132: 428-432.

[10] Wanasundera, J.P., \& Ravindran, G., 1994. Nutritional assessment of yam (Dioscorea alata) tubers. Plant Foods for Human Nutrition. 46 (1): 33-39.

[11] Choi, E.M., \& Hwang, J.K.,2002. Enhancement of oxidative response and cytokine production by yam mucopolysaccharide in murine peritoneal macrophage. Fitoterapia, 73 (7-8): 629-637.

[12] Jan, T.R., Wey, S.P., Kuan, C.C., Liao, M.H., \& Wu, H.Y., 2007. Diosgenin, a steroidal sapogenin, enhances antigen-specific IgG2a and interferon-gamma expression in ovalbumin-sensitized BALB/c mice. Planta Medica, 73 (5): 421-426.

[13] Lin, P.L., Lin, K.W., Weng, C.F., \& Lin, K.C., 2009. Yam storage protein dioscorins from Dioscorea alata and Dioscorea japonica exhibit distinct immunomodulatory activities in mice. Journal of Agricultural and Food Chemistry, 57 (11): 4606-4613.

[14] Lu YL, Chia CY, Liu YW, Hou WC. 2012. Biological activities and applications of Dioscorins, the major tuber storage protein of yam. Journal of Traditional and Complementary Medicine. Vol. 2. No.1. 41-46.

[15] Gurfinkel, D.M., and Rao, A.V., 2003. Soyasaponins: The relationship between chemical structure and colon anticarcinogenic activity. Nutr. Cancer, 47: 24-33.

[16] Kim, S.W., Park, S.K., Kang, S.I., Kang, H.C., Oh, H.J., Bae, C.Y., and Bae, D.H., 2003. Hypocholesterolemic property of Yucca schidigera and Quillaja saponaria extracts in human body. Arch. Pharm. Res., 26: 1042-1046.

[17] Bhandari, M.R., Kawabata, J., Kasai, T., 2003. Nutritional Evaluation of Wild Yam (Dioscorea spp.) Tubers of Nepal. Food Chemistry, 82: 619-623. Elsevier.

[18] Kumar, S., Das, G., Shin, H-S., and Patra, J.K., 2017. Dioscorea spp. (A Wild Edible Tuber): A Study on Its Ethnopharmacological Potential and Traditional Used by the Local People of Similipal Biosphere Reserve, India (Review). Frontiers in Pharmacology. 8: 52. Doi: 10.3389/fphar.2017.00052.

[19] Johnston, M. and Onwueme, I.C., 1998. Effect of Shade on Photosynthetic Pigments in The Tropical Root Crops: Yam, Taro, Tannia, Cassava and Sweet Potato. Expl. Agric., 34: 301-312. 
[20] Coursey, D.G., 1967. Yams: An Account of the Nature, Origins, Cultivation and Utilization of the Useful Members of the Dioscoreaceae. London: Longmans, Greens and Co. Ltd.

[21] Hahn, S.K., 1995. "Yams, Dioscorea spp. (Dioscoreaceae)," In Evolution of Crops Plants, eds J. Smartt and N.W. Simmonds (London: Longman Group Limited), 112-120.

[22] Alexander, J., and Coursey, D.G., 1969. "The origins of yam cultivation," in The Domestication and Exploitation of Plants and animals. Proceedings of a Meeting of the Research Seminar in Archaeology and Related Subjects Held at the Institute of Archaeology, London University, eds P.J. Ucko and G.H. Dimbleby (Gerald: Duckworth \& Co. Ltd.),405-425.

[23] Badan Pusat Statistik Kabupaten Manokwari. 2017. Kabupaten Manokwari Dalam Angka 2017. Badan Pusat Statistik Kabupaten Manokwari, Kabupaten Manokwari. Manokwari. (Central Bureau of Statistics of Manokwari Regency, 2017)

[24] Arnau, G., Abraham, K., Sheela, M.N., Chair, H., Sartie, A., and Asiedu, R., 2010. Chapter 4 Yams: in Root and Tuber Crops, Handbook of Plant Breeding, (ed.), Bradshaw, J.E. DOI 10.1007/978-0-387-92765-7-4.

[25] Orkwor, G.C., Asiedu, R. and Ekanayaka, I.J. 1998. Food Yams: Advances in Research. Ibadan: International Institute of Tropical Agriculture/NRCRI.

[26] Tamiru, M.2006. Assesing Diversityin yams (Dioscorea spp.) from Ethiopia Based on Morphology , AFLP Markers and Tuber Quality and Farmer's Management of Landraces. PhD. Thesis, GeorgAugust-University, Goettingen.
[27] Terauchi, R., Terachi, T., Tsunewaki, K. 1991. Intraspecific variation of chloroplast DNA in Dioscorea bulbifera L. Theor. Appl. Genet. 81, 461-470. doi: 10.1007/BF00219435.

[28] Onwueme, I. C. and Charles, W. B. 1994. Tropical Root and Tuber Crops: production, prospective and future prospects, in FAO Plant Production and Protection Paper. Pp 1-228. Rome.

[29] Schultz, G. E. 1993. Element Stewardship Abstract for Dioscorea bulbifera. The Nature Concervancy. Available on line at: http://www.invasive.org/weeded/pdfs/tncweeds/diosbul.pdf.

[30] Langland, K. A. and Burks, C. K., 1998. Identification and Biology of Non-native Plants in Florida's Natural Areas. Gainesville, FL. University of Florida.

[31] Ayensu, E.S., and Coursey, D.G., 1972. Guinea yams: the botany, ethnobotany, use and possible future of yams in West Africa. Econ. Bot. 26, 301-318. Doi: 10.1007/BF02860700

[32] Sharma, L.N. and Bastakoti, R. 2009. Ethnobotany of Dioscorea L. with emphasis on food value in Chepang communities in Dhading District, central Nepal.Botanica Orientalis. J. Plant Sci. 6, 12-17.

[33] Nashriyah, M., Athiqah, M.Y.N., Amin, H.S., Norhayati, N., Azhar, A.W.M., Khairil, M., 2011. Ethnobotany and Distribution of Wild Edible Tubers in Pulau Redang and Nearby Islands of Terengganu, Malaysia. International Journal of Nutrition and Food Engineering. 5(12): 911-914.

[34] French, B.R., 2006. Root Crops and Starchy Staple Foods. In: Food Plants of Papua New Guinea. A compendium Revised edition. Pp.2332. 